\title{
简析台风“利奇马” 对绥中的影响
}

\section{张晓丹 吴琼 苏慧 虞帅}

绥中县气象局

DOI:10.32629/eep.v2i10.481

[摘 要] 利用常规天气图、数值预报产品资料,对2019年台风 “利奇马” 减弱后的热带低压进行综合分析,主要针对2019年8月10一12日其影响 绥中的一次台风北上过程进行个例研究,结果表明: 此次天气过程主要由台风减弱后的热带低压、冷空气和地面气旋共同影响造成的,系统动力 抬升条件好,水汽输送条件好, 导致绥中多个站点出现暴雨和大暴雨天气。

[关键词] 热带低压、暴雨、水汽输送

台风灾害多是由台风暴雨引起的, 目前对台风暴雨的研究较为广泛 1。绥中县位于辽宁省西南部, 南邻渤海, 属于亚湿润区季风型大陆性气 候。由于地形特点, 近二十年来受台风直接影响次数较少。2019年受 9 号 台风 “利奇马” 影响, 绥中出现暴雨到大暴雨天气。此次天气过程是受 北上台风影响的暴雨个例, 因此有必要对其进行分析, 以不断积累北上 台风暴雨预报经验。

\section{1 台风概况}

8 月 10 日 01 时 45 分, 台风在温岭市城南镇沿海登陆。随后, 纵穿浙江、 江苏两省, 后移入黄海海面。8月11日20时50分在山东省青岛市沿海再次 登录。后期移入渤海海面并不断减弱。13日14时, 中央气象台对其停止 编号。

\section{2 降水实况}

10 日 1 时到 13 日 23 时全县最大降水量： $347.3 \mathrm{~mm}$ (塔山屯镇天龙寺 港), 24 个乡镇平均降雨量: $199.5 \mathrm{~mm}$, 乡镇最大降水量: $279.7 \mathrm{~mm}$ (加碑岩), 所有乡镇降水量均超过 100 毫米, 降水量超过 200 毫米的乡镇 12 个。

各乡镇降水量 (单位: $\mathrm{mm}$ )

\begin{tabular}{|c|c|c|c|c|c|c|c|c|c|c|c|}
\hline 绥中 & 276.3 & 加碑岩 & 279.7 & 网户 & 267.6 & 荒地 & 224.3 & 前 卫 & 221.7 & 王宝 & 219.7 \\
\hline 高岭 & 219.0 & 西平 & 215.7 & 大王庙 & 211.4 & 高台 & 208.9 & 明水 & 207.0 & 沙河 & 203.6 \\
\hline 高甸子 & 197.6 & 小庄子 & 190.0 & 前所 & 187.2 & 万家 & 173.3 & 西甸子 & 169.2 & 塔山 & 166.2 \\
\hline 李家 & 164.2 & 葛家 & 161.8 & 永安 & 161.0 & 秋子沟 & 160.2 & 宽邦 & 154.6 & 范家 & 148.9 \\
\hline
\end{tabular}

\section{3 环流演变与水汽条件分析}

形成降水的最基本条件有两个, 即充沛的水汽和上升运动 2 。这次台风 大暴雨过程是在热带、副热带、西风带系统共同作用下出现的。台风北上 与西风槽结合, 相互的叠加作用给绥中带来强降水。

10 日01时, 台风带来的暖湿空气与冷空气结合, 在辽西一带形成锋面 系统, 12 日 08 时, 如图一所示, 随西风槽东移南压, 热带低压北上与之结合, 系统合并后移动较慢, 中心位于山东北部。如图二所示, 850hpa低压环流倒 槽已影响辽宁西部, 绥中处于倒槽右前方, 配合地面倒槽形成辐合 (图三), 动力条件非常有利。12日20时, 台风外围的东南风急流源源不断的输送水 汽, 低层风速在 $16 \mathrm{~m} / \mathrm{s}$, 从 $850 \mathrm{hPa}$ 相对湿度和风场可以看出, 绥中地区为主 要的辐合区, 随着系统逐渐向东北推进, 绥中的水汽通量辐合愈加有利, 12 日夜间强降水开始。

事实上, 10 日03时降水从绥中西南地区开始, 遍布全县范围, 11 日 21 时至 12 日 20 时降水加强, 全县平均降水量为 $93.5 \mathrm{~mm}$, 最大降水量为 153. $4 \mathrm{~mm}$ 。小时雨强加强时段为 07 时至 15 时, 全县最大小时雨强为 $23.5 \mathrm{~mm}$ 。

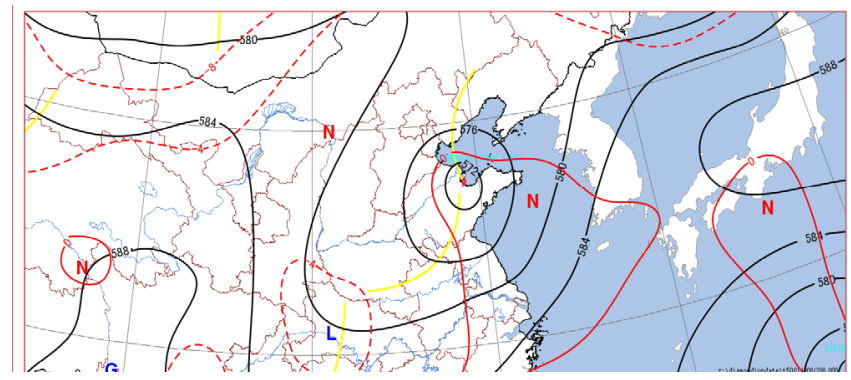

图一 12 日08时500hpa环流形势

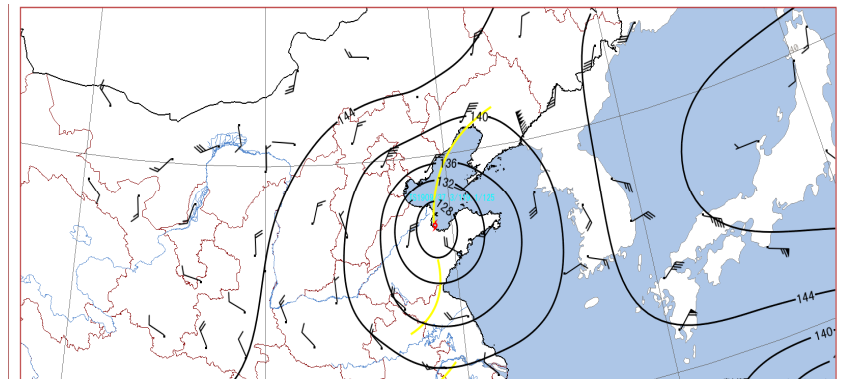

图二 12 日08时850hpa环流形势

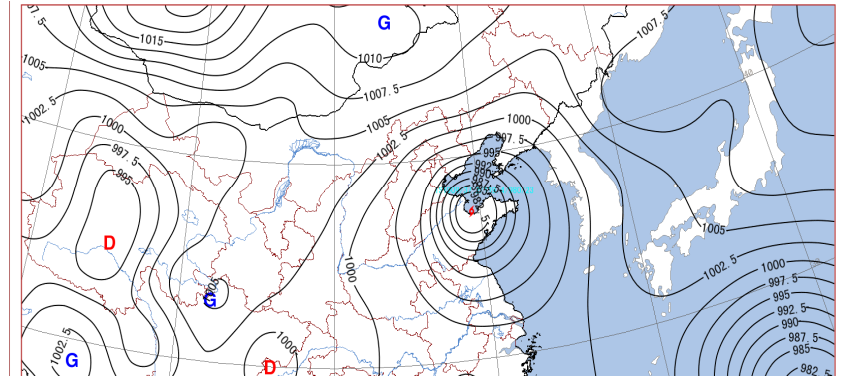

图三 12 日08时地面形势

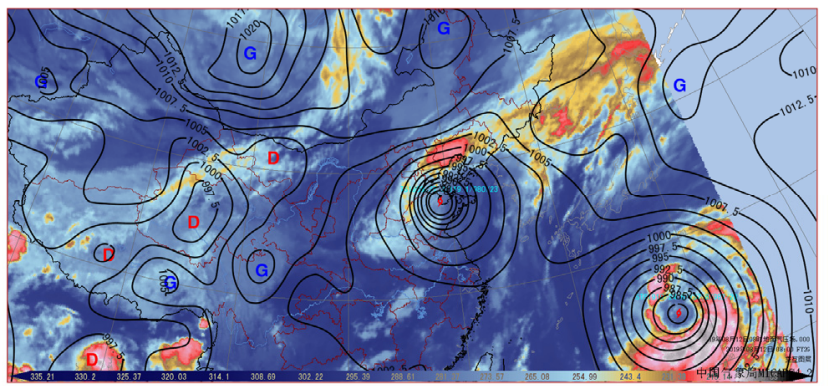

图四 水汽条件 


\title{
探析林业工程建设中的林木种苗培育技术
}

\author{
郭丽霞
}

河南省漯河市召陵区姬石镇政府

DOI:10.32629/eep.v2i10.489

[摘 要] 在我国社会经济持续发展的背景下,林业事业取得了多元化发展,林木种苗培育技术是林业工程建设的主要技术,对林业工程事业持续 健康发展有非常重要的作用。但就目前我国林木种苗培育技术发展现状而言,还存在很多问题亟待解决。基于此, 本文结合理论实践,在简要阐 述林木种苗培育技术重要性的基础上,分析了目前发展现状,并提出此项技术在林业工程建设中的具体应用路径及应用要点,希望我国林业工程 建设发展有一定的参考及借鉴。

[关键词] 林业工程; 林木; 种苗; 培育技术

\section{引言}

林业工程发展水平, 对一个国家社会经济持续稳定发展有非常重要 的意义。发展林业工程, 既能促使我国林业事业长久发展, 也可以净化空 气, 改善空气质量, 实现节能减排。目前我国空气污染非常严重, 亟待全 面改革优化。就我国目前林业工程发展现状而言, 还存很多问题需要解 决, 主要原因在林业工程建设中, 多采用传统种植方式, 效率比较低。在 科技化时代, 将先进的技术应用到林木种苗培育中, 可大幅度提升林木 种苗培育的成活率、抗旱性、抗病虫害能力, 从而促使我国林业工程事 业持续发展。基于此, 开展林业工程建设中的林木种苗培育技术分析就 显得尤为必要。

\section{1 发展林木种苗培育技术的重要性}

1. 1有利于推动林业工程事业持续发展

在林业工程建设中, 需要用到大量优质林木种苗。为提升林业工程建 设效率, 需要综合考虑区域地质条件、水文条件、气候条件等, 然后应用 先进的林木种苗培育技术。在我国环境污染不断加剧的背景下, 国家越来 越重视林木种苗培育技术, 并将此项技术的应用和发展纳入法律制度建设 中, 大大提升了林业工程建设步伐, 为我国林业工程建设活动实现持续发 展提供了技术支持。

\section{2 有利于提升林业工程建设规模}

在林业工程产业化建设发展大环境下, 对林木种苗的数量、质量、种 类都提出了更高的要求, 这就对现代化林木种苗培育工作造成了较大影 响。同样, 林业工程建设要想实现规模化发展, 就必须借助林木种苗培育技 术的优势, 以实现综合性发展。促使林业工程建设事业实现产业化升级, 以便更好的改善区域生态环境, 发挥林木防风固沙的作用, 也构件生态环 境的主要方式 ${ }^{[1]}$ 。

\section{3有利于构建林业工程生态体系}

近年来, 我国林业工程建设发展了极大改变, 发展的核心已经不是林 木种植的数量, 而且林业种植质量管理为核心, 以便更好的优化生态系统,

\section{4 结论}

此次降水过程主要由台风减弱后的热带低压、冷空气和地面气旋共同 影响造成的, 系统动力抬升条件好, 水汽输送条件好, 导致绥中多个乡镇出 现暴雨和大暴雨天气。

台风一方面能带来充足的雨水, 成为较大的降水系统, 另一方面也具 有破坏力 3 , 影响人们的生产生活。受此次过程影响, 绥中部分乡镇大田作 物、设施农业受淹, 防洪堤坝损毁, 河道冲毁, 桥梁、公路受损。因此只有 不断积累和提高台风暴雨预报经验, 才能更好的为人民生活和农业生产提
促使我国林业工程事业持续发展。发展核心的转变, 需要优质林木种苗的 支持和保证。

\section{2 目前我国林木种苗培育技术发展现状}

2.1 受到气候环境的影响比较大

林木种苗培育周期比较长, 具有很强的周期性及系统性, 对周围环境 的温度、温度有很高的要求。通过当地气候环境发展变化, 必然会影响林 木种苗培育的质量及成本, 也不利于林木种苗市场竞争力的提升。

\section{2 专业度不够}

我国林木种苗培育技术研究和应用起步比较晚, 目前仍然处于发展的 初级阶段,一些育种方式比较滞后, 多采用先播种, 后扦插的方式来育种。并 没有充分应用林木种苗培育专业技术, 质量和产量普遍较低, 无法满足林 业工程建设高速发展的要求。

2.3 林木种苗培育过程不够规范

目前我国林木种苗培育的规模普遍比较小, 主要体现在两个方面: 其 一林木种苗培育技术比较滞后, 其二缺乏充裕的资金, 也导致林木种苗培 育过程缺乏规范性的主要原因 ${ }^{[2]}$ 。

2. 4 生产结构不够平衡

我国各地林业工程建设中, 林木种苗培育主要呈现“裸根苗多, 容器苗 少”、“留床苗多, 定植苗少”、“普通苗多、经济苗少” 的特性。此外, $1^{\sim} 3$ 年生林木种苗比较多, 3 年以上的林木种苗比较少。

\section{3 林木种苗培育技术在林业工程建设中的应用路径}

3. 1 确定林木种苗培育程序

林木种苗生长需要经历一套程序, 主要分为三个生长周期, 其一是 幼苗建成期; 其二高生长时期; 其三是木质化时期。三个生长周期, 又 可细分为多到程序, 包括: 林木种植催芽、育苗基质制备、容器选择、 播种和覆盖、浇水和施肥, 控制基质 $\mathrm{pH}$ 值、控制土壤盐渍化等。任何一 道程序控制不当, 或者发生问题, 都会影响林木种苗培育效果, 从而影响 林木种苗的成活率及生长的活力。

供更精准的气象服务, 减少损失。

[参考文献]

[1]姜建丰,余霖枫,包国雅.一次热带低压引发的泰顺县暴雨过程的分 析[J].南方农业,2019,13(14):142-143.

[2]陈淑琴,徐炎, 曹宗元, 等.冷空气和热带低压共同作用下的一次暴雨 预报失败原因分析[J].气象,2018,44(01):142-150.

[3]张思豆, 张腾飞, 曹杰.云南2次西行台风暴雨过程数值模拟和诊断 分析[J].云南大学学报(自然科学版),2017,39(06):1012-1022. 